\title{
Bioenergy production in the Toruń biogas plant (Poland)
}

\author{
Bartłomiej Igliński ${ }^{1 *}$, Jerzy Sobólski ${ }^{2}$ \\ ${ }^{I}$ Nicolaus Copernicus University, Toruń, Poland \\ ${ }^{2}$ Biogaz Inwestor Co., Toruń, Poland \\ *Corresponding author.Tel: +48 0566114331,Fax: +48 0566542477,E-mail: iglinski@chem.umk.pl
}

\begin{abstract}
This paper describes the work of the biogas plant in Torun (Poland). Biogas has been obtained from municipal waste since 1998 at the Municipal Waste Landfill Site in Torun. Biodegradable waste constitutes about $45-50 \%$ of the waste dumped into the site. These municipal wastes have been disposed of at this site since 1964. Biogas is obtained during approximately 8000 hours per year from 62 wells. The highest methane contents in biogas (>60\%) were achieved between 2000-2003 and in 2008. As a result of biogas combustion, thermal and electrical energy is produced. The total quantity of energy produced during a year is $11000 \mathrm{MWh}$, but higher amounts were achieved in 2004 and 2008 (nearly $12500 \mathrm{MWh}$ ). The heat and electrical energy obtained is supplied to the city inhabitants by the Power Station Torun S.A. and the Thermal Energy Station Torun Co. Ltd.
\end{abstract}

Keywords: bioenergy, biogas, Toruń, municipal wastes

\section{Introduction}

Biogas is one of the most important renewable energy sources [1,2]. Known also as a waste site gas, biogas is heavier than air. Regardless of the substrate, it has two major components methane and carbon dioxide. Biogas is obtained from waste biomass [3,4]. This covers a wide and difficult to manage range, starting from forest and farming wastes (including fermented liquid manure) through sewage sludge to municipal wastes $[5,6]$.

The Municipal Waste Landfill Site in Torun (Fig. 1) is designated, mostly, for municipal wastes. The site is located in the northern part of the city, in the industrial district, $10 \mathrm{~km}$ away from the city centre. The location complies with the local spatial management plan -in the area designated for the municipal waste disposal complex. The site is located on a plain with little altitude differences, with ground declination toward the south and the current Vistula Valley, located $3.5 \mathrm{~km}$ away.

Fig.1. Location of biogas installation.

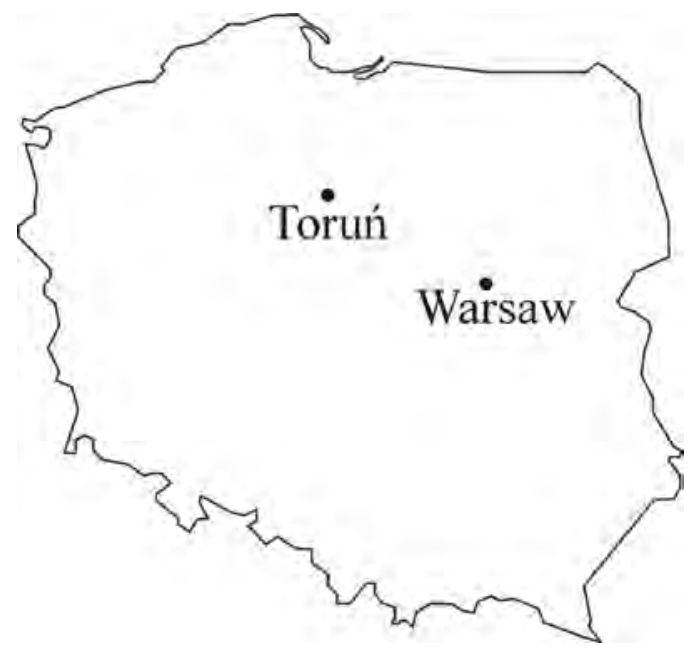

The wastes have been disposed of at the site since 1964. Originally solid and liquid wastes were dumped without any formal or legal agreement in an unregulated manner. Since its 
modernisation in 1993, the waste landfill site has been functioning as a legally sanctioned waste site for the city of Torun.

The total area of the site is 12.1 ha, including:

- two landfill sections of total area of 8.5 ha, exploitation time 1964/86 and 1992/95 there are no safeguards against leaches to underground waters; these are the areas the waste site gas-biogas is obtained from,

- post-discharge terrace of total area of $1.7 \mathrm{ha}$; until 1991 in this area there used to function two partially proofed landfill sections for industrial post-discharge sludge,

- landfill section of area of 1.9 ha, used since 1995, so called "basin" - proofed with geo-membrane HDPE $1.5 \mathrm{~mm}$ with a built-up sewage drainage system.

On December $31^{\text {st }} 2009$ the waste site was closed. It is estimated that biogas from the dumped waste will be exploited for the next 15-20 years. In the near future a further biogas installation is to open at a new, nearby waste site.

\subsection{The type and amount of waste dumped at the site}

The landfill waste site in Torun is a target place for municipal waste disposal as well as the disposal of industrial waste, qualified to be disposed there, as a result of the decisions of the competent administration authorities. At the site there are no wastes considered to be dangerous substances according to environmental protection regulations. Table 1 shows the composition of wastes. The major components of municipal waste are organic wastes, which are subject to the natural process of biodegradation. In Torun biogas is obtained from nonsegregated waste, which is a result of the lack of pro-ecological management in the 1970s in Poland. The biodegradable wastes constitute about $45-50 \%$ of the stream of municipal wastes. The amount of dumped waste is estimated at $2500000 \mathrm{Mg}$.

Table 1. The composition of municipal waste of the city of Torun (\%).

\begin{tabular}{cccc}
\hline \multirow{2}{*}{ Fraction } & \multicolumn{3}{c}{ Year } \\
\cline { 2 - 4 } & 1991 & 2000 & 2009 \\
\hline Plant food waste & 25.2 & 14.8 & 14.4 \\
Animal food waste & 4.3 & 1.0 & 0.0 \\
Other organic waste & 3.4 & 8.8 & 14.2 \\
Paper and cardboard & 13.4 & 18.7 & 12.3 \\
Plastics & 5.1 & 19.9 & 11.2 \\
Textile waste & 4.4 & 3.5 & 2.5 \\
Glass & 6.9 & 12.0 & 7.6 \\
Metals & 3.4 & 2.8 & 5.4 \\
Other mineral waste & 6.9 & 4.7 & 3.4 \\
Fraction $<10$ mm & 27.0 & 13.8 & 29.0 \\
\hline
\end{tabular}

\section{The system for obtaining biogas in the Toruń biogas plant}

In 1991-1992, within the framework of the programme to improve the natural environment, research was conducted in Poland to examine $15 \mathrm{~m}$ unicipal waste landfill sites in order to check the amount and quality of biogas. At the waste site in Torun, 6 gas wells were built that ran $16 \mathrm{~m}$ deep into the bowl of the site. After 800 hours of work, the mean parameters of obtained biogas were satisfactory $\left(61.1 \% \mathrm{CH}_{4}, 28.8 \mathrm{CO}_{2}, 0.1 \% \mathrm{O}_{2}\right)$. The initial analysis, as well as the further research, confirmed that the biogas produced at the municipal waste landfill site in Torun is adequate for commercial use. 
In 1993 a request was made for financial support from the Thermie programme in order to build a pioneering installation for obtaining and utilising waste site gas in Torun. With the support of the European Union Commission, a contract was signed to realise this project and to finance it at $30 \%$ of net costs. In order to build and operate a modern waste site gas utilisation unit, a new company was established - Biogas Investor Co. Ltd. The investment was partially financed by the National and Voivodship Environmental Protection Fund as well as by $30 \%$ subvention from the European Union, allocated as a part of the Thermie programme.

The gas from waste landfill piles started being used on 10 September 1997. On 10 September 1999 additional works were finished and a use permit was obtained. In 2001 the maximum technical and production parameters were achieved. The gas production covered 11 ha of the waste site near Kociewska Street in Torun. In this area 40 gas wells were drilled (Fig. 2), which are boreholes $16 \mathrm{~m}$ deep and suction pipes were laid. The system is equipped with a technical biogas suction apparatus (MPR), gas mains, thermal-electric mains (CHP) of power $550 \mathrm{~kW}_{\mathrm{e}}$ and $770 \mathrm{~kW}_{\mathrm{t}}$. The thermal-electric power station is connected to the heating and power network. The whole system is totally automatic and computer directed. In April 2002 a further 3 ha of the waste landfill site were covered by degassing equipment as 12 new biogas wells were built and utilised as a part of the system.

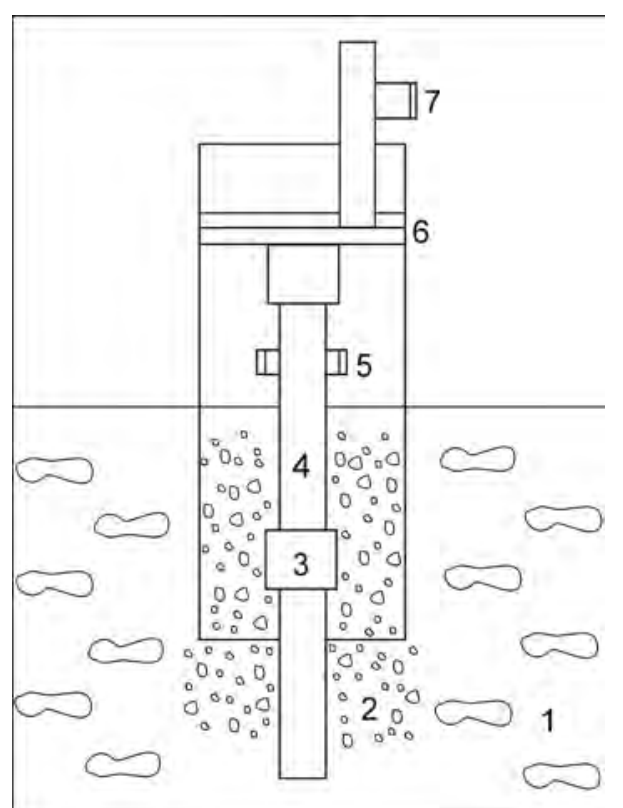

Fig. 2. Construction of wells: 1-waste, 2 - gravel, 3 -plug-in muff, 4 -degassing pipe, 5 -gas intake, 6-gas proof cover, 7 - pipe line.

In January 2004 the second power-producing unit of power $324 \mathrm{~kW}$ e was opened, which marked the end of the first stage of development of the system for obtaining and utilisation of waste site gas. During this stage, 12 wells, $2788 \mathrm{~m}$ of gas pipes, a transformer station, wire line NN were built and a power-generating system was bought. Since 1 March 2004 the biogas system has been working at the power of $698 \mathrm{~kW}_{\mathrm{e}}$ and $770 \mathrm{~kW}_{\mathrm{t}}$ - utilising $440 \mathrm{Nm}^{3} / \mathrm{h}$ of waste site gas obtained from municipal waste piles of $16 \mathrm{~m}$ height and 14 ha base.

In 2007 and 2009 r espectively 17 and 5 new wells were built. In $200912 \mathrm{w}$ ells of low efficiency were closed. Currently, biogas is obtained from 62 wells. 


\section{Biogas production in the Toruń biogas plant}

The biogas obtained from the degassing wells is transported via gas pipes to an MPR module, where suction and pumping equipment, a gas composition analyser and flow meters showing the flow in particular gas wells. Transported from an MPR module by a common pipe, gas from individual wells is then sent to the decanter, where water contained in the biogas is outdropped. After drying, depending on the requirements, biogas is directed to the module generating electrical power and heat or to the power generating system operating since 2004 . The composition of gas taken from each well is constantly monitored using the stationary analyser SATGAS 800 (S.A. TechnikAS, Denmark). The content of $\mathrm{CH}_{4}, \mathrm{CO}_{2}$ and $\mathrm{O}_{2}$ is analysed, the remaining part is assumed to be $\mathrm{N}_{2}$. The collection of biogas is fully controlled: in situations where the methane concentration decreases below $40 \%$ or oxygen concentration increases above $0.3 \%$, the well is closed.

Fig. 3 represents the amount of biogas obtained between 1998 and 2009. The least amount of biogas was obtained at the first start-up (1998), and in $2002 \mathrm{w}$ hen maintenance work was carried out. Since 2003 when 12 new wells were opened, the amount of obtained biogas has risen by $50 \%$. The highest methane content in biogas (>60\%) was achieved in 2000-2003. Since 2004 a decrease in methane content has been observed, which is contributed to the ageing of resources from which biogas is obtained. This phenomenon is partially caused by the common use of virtually non-degradable foil bags for rubbish collection in Poland. Having arrived at the site, these bags create a specific geo-membrane, making it difficult for nutrients and water to penetrate into deeper parts of the waste site. Water content is essential to the development of microorganisms. When the content of dry matter is higher than $40 \%$, the life processes of microorganisms are disturbed, which leads to a lower methane content of the biogas and smaller quantities of biogas produced. One of the solutions aimed at avoiding the geo-membrane issues created by the waste foil is to use a mill to crush waste prior to dumping it onto the waste site. When the methane content drops below $40 \%$, it is planned to use natural gas to aid the biogas stream fed into the engine. This will make the combusted gas more calorific and extend the working lifetime of the biogas site. It will also mean that the power of installed equipment is fully used. Opening new wells as well as closing the inefficient ones leads to increased methane content in biogas. 


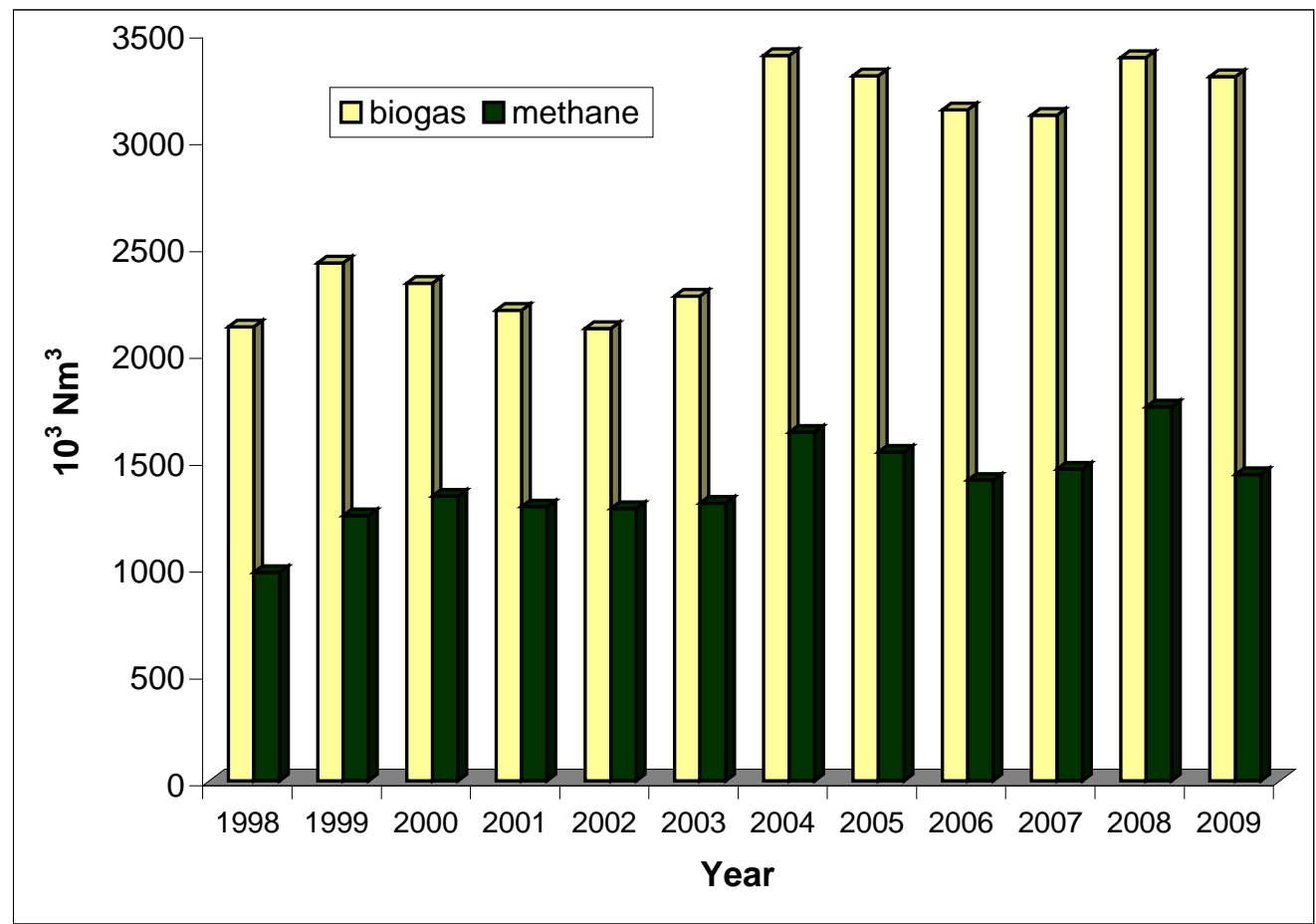

Fig. 3. The amount of biogas and methane obtained in 1998-2009.

Biogas is obtained during 8000 hours annually. The highest mean electric power generated was achieved during the last six years, which was influenced by the new wells and the second power-generating system being opened. Apart from the first year of start-up (1998), the mean thermal power has remained at the same level. The amount of heat produced was $25 \%$ higher than the amount of electrical power over the years 1998-2007. Since 2008 the amounts of heat produced and electric power have been at a similar level (6000 MWh).

The total amount of energy produced over a year stays at the level of $11000 \mathrm{MWh}$ (Fig. 4), but the highest amounts were achieved in 2004 and 2008 (nearly $12500 \mathrm{MWh}$ ). The obtained heat and electric energy is supplied to the city inhabitants by the Power Station Torun S.A. and the Thermal Energy Station Torun Co. Ltd.

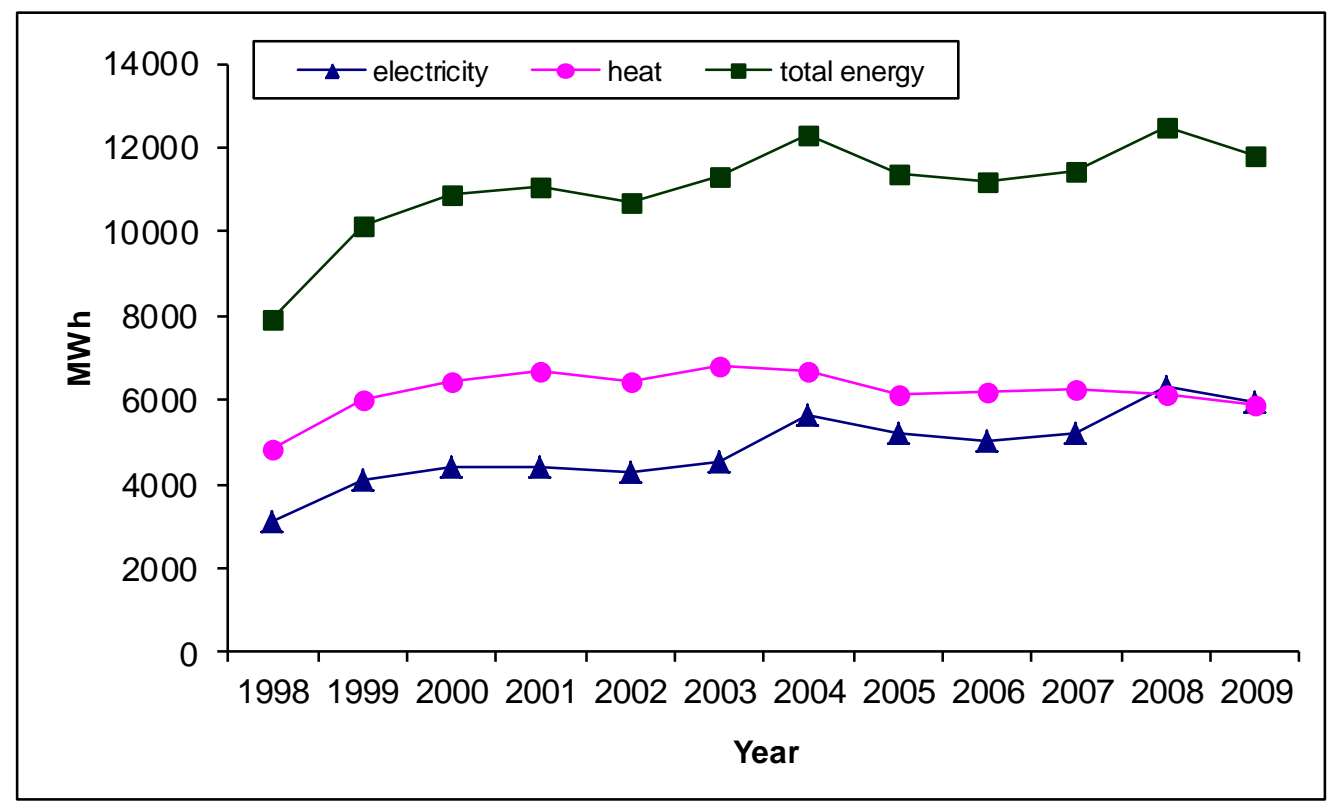

Fig. 4. Electricity and heat prduction in 1998-2009. 


\section{Perspectives of biogas production in biogas plant in Toruń}

During most of the operation time of Torun landfill installation there was no record of waste deposited there. Apart from the municipal waste, the industrial (hazardous) waste was also deposited, including bricks, tires and chemical waste. Thus, it is only possible to estimate the amount of biogas and methane content in landfil gas using the results obtained so far. Currently, the next twenty wells are to be built at the landfill site in 2011, which is going to increase the amount and quality of biogas in comparison to the previous years (Fig. 3). Within the following years (after 2011) the quality of biogas as well as methane content in LFG will continue to deplete and biogas parameters will be gradually decreasing. In the near future a new biogas installation will operate at a new municipal landfill site in Torun.

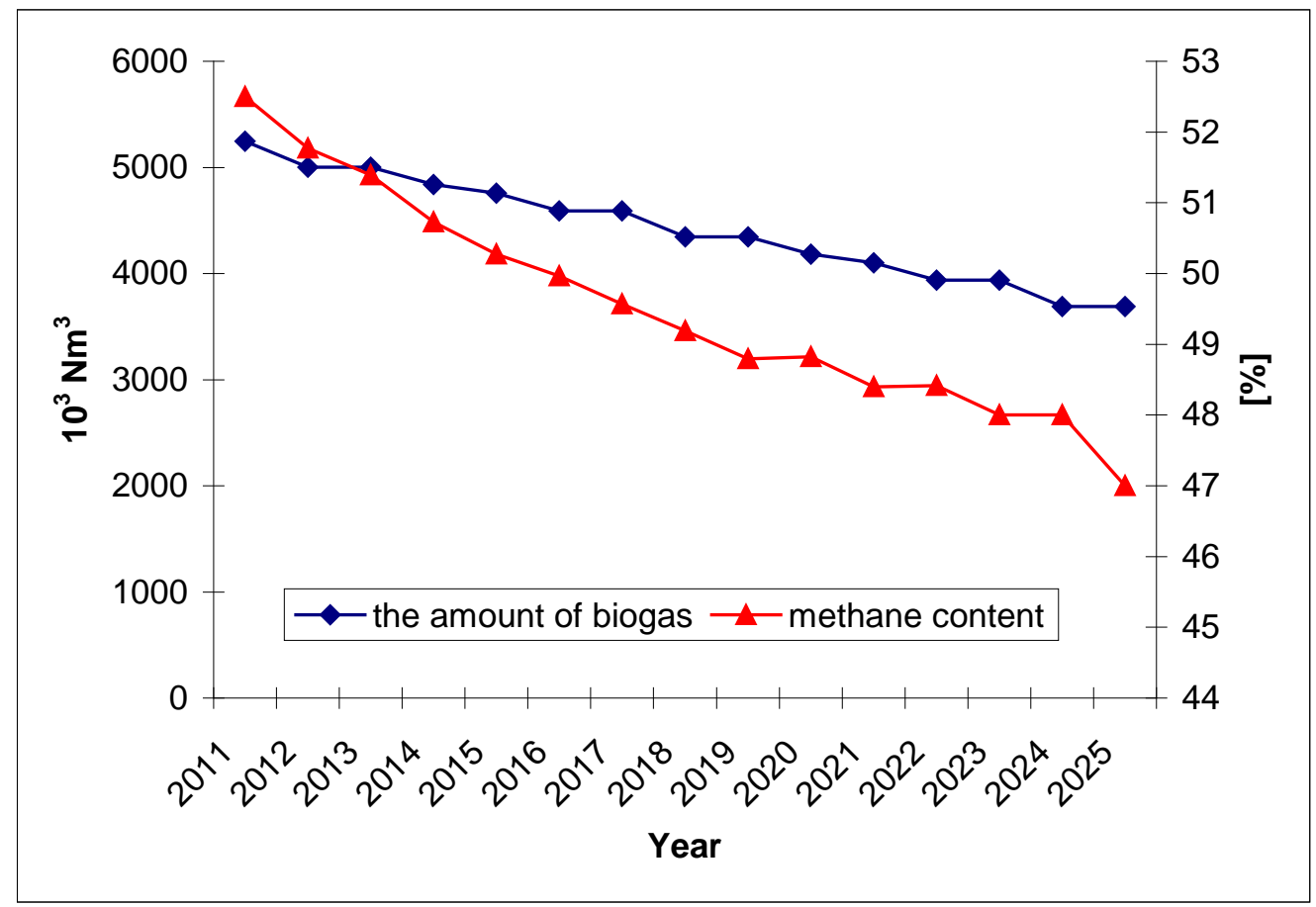

Fig. 5. Estimated amount of biogas and methane content.

\section{Ecological effect of biogas production}

The biogas installation in Torun ensures the utilisation of biogas created at the municipal waste landfill site. The major component of biogas - methane - is a highly flammable and explosive gas. A fire at the waste site could be very difficult to control and could last over months, emitting during this time considerable amounts of $\mathrm{CO}_{2}, \mathrm{CO}$, dioxins, furans and soot. Methane is one of the gases with a strong impact on the green house effect. Research has shown [9] that methane emission from waste landfill sites causes the green house effect 25 times higher than that caused by carbon dioxide [10].

Between 1998-2009, $33095283 \mathrm{~m}^{3}$ of biogas was utilised, including $16626081 \mathrm{~m}^{3}$ of methane, which corresponds to $75213 \mathrm{Mg}$ of lignite ("brown coal") or $30815 \mathrm{Mg}$ of hard coal. Combustion of such an amount of coal would lead to the emission of $\mathrm{CO}_{2}, \mathrm{CO}, \mathrm{SO}_{2}, \mathrm{NO}_{\mathrm{x}}$ and of dusts. Obtained biogas is burnt at the location where it is produced (Toruń), whereas hard coal needs to be transported from the mines (Upper Silesia - 300-400 km), which also involves the emission of harmful gases and increases the cost of its production $[11,12]$.

In the near future it is planned for all the public transport vehicles and the Municipal Waste Management Services vehicles to be fuelled by natural gas with the addition of treated biogas. 
The Gas Fuels Station in Torun was opened in 2008 for this purpose and the first buses are now testing the gas fuel $[2,13]$.

\section{Conclusions}

Torun waste site gas recovery and utilisation installation, combines the production of electrical and thermal energy, it is the first one in this part of Europe to be equipped with such modern technology. It eliminates the negative impact of waste site gas emission, which would enhance the greenhouse effect and contribute to ozone layer destruction. Additionally it also produces green thermal and electrical power, which improves the environment of historic Torun, the Old Town of which is on the UNESCO heritage list [13].

Summing up the possibilities offered by alternative energy sources, it must be stressed that their use seems essential to the country that wants to lead a policy of balanced development. Before we ask how many new coal power plants to build and whether nuclear energy should be developed, we should try to answer the alternative questions - what resources there are in rationalization and how much energy can be provided by renewable, environmentally friendly energy sources.

\section{References}

[1] P. Weiland, Biogas production: current state and perspectives, Applied Microbiology and Biotechnology 85, 2010, pp. 849-860.

[2] B. Igliński, R. Buczkowski, M. Cichosz, Bioenergy technologies, Nicolaus Copernicus University Publishing, 2009, pp. 255-298.

[3] J.D. Murphy, E. McKeogh, G. Kiely, Technical/economic/environmental analysis of biogas utilisation, Applied Energy 77, 2004, pp. 407-427.

[4] J.D. Murphy, E. McKeogh, Technical, economic and environmental analysis of energy production from municipal solid waste, Renewable Energy 29, 2004, 1043-1057.

[5] R. Buczkowski, A. Iglińska, B. Igliński, The possibilities of obtaining biomass for biogas production in the region of Torun, Chemistry for Agriculture 7, 2006, pp. 865-869.

[6] R. Kothari, V.V. Tyagi, A. Pathak, Waste-to-energy: A way from renewable energy sources to sustainable development, Renwable and Sustainable Energy Reviews 14, 2010, pp. 3164-3170.

[7] U. Desideri, F. Di Maria, D. Leonardi, S. Proietti, Sanitary landfill energetic potential analysis: a real case study, Energy Conversation and Management 44, 2003, pp. 1969 1981.

[8] R. Arthur, M.F. Baidoo, E. Antwi, Biogas as a potential renewable energy source: A Ghanaian case study, Renewable Energy 36, 2011, pp. 1510-1516.

[9] Website: http://www.ipcc.ch/pdf/assessment-report/ar4/wg1/ar4-wg1-chapter2.pdf

[10]C. Cornejo, A.C. Wilkie, Greenhouse gas emission and biogas potential from livestock on Ecuador, Energy for Sustainable Development 14, 2010, pp. 256-266.

[11]L.J. Nilsson, M. Pisarek, J. Buriak, A. Oniszk-Popławska, P. Bućko, K. Ericsson, Ł. Jaworski, Energy policy and the role of bioenergy in Poland, Energy Policy 34, 2006, pp. 2263-2278.

[12]J. Paska, M. Salek, T. Surma, Current status and prospectives of renewable energy sources in Poland, Renewable and Sustainable Energy Reviews 13, 2009, pp. 142-154. 
[13]B. Igliński, W. Kujawski, R. Buczkowski, M. Cichosz, Renewable energy in KujawskoPomorskie Voivodeship(Poland), Renewable and Sustainable Energy Reviews 14, 2010, pp. 1336-1341. 